\title{
Somesh K.Mathura
}

\begin{abstract}
The paper reviews the sources of market failure in financial institutions and markets and what can be done to alleviate them. It examines game-theoretic explanations for financial instability, in particular the role of asymmetric information in generating destabilising behaviour. In the area of remedies, the paper analyses the potential contribution of official safety nets and what can be done to minimize the associated moral hazard. In this context, it discusses the role of regulation and transparency.
\end{abstract}

\section{Introduction}

A considerable amount of discussion has been generated in recent times on the issue of financial stability. It is well recognized that safeguarding financial stability is of central importance to overall macro-economic stability. It provides the basis for rational decision-making about the allocation of real resources through time, and in the absence of imperfections in the real sector, improves the climate for savings and investment. The absence of stability creates damaging uncertainties that can lead to resource misallocation and reduce the willingness of agents to enter into inter-temporal contracts. Recent interest in financial stability has been driven by two major considerations. First, advancements in finance have provided a coherent macroeconomic foundation for studying manifestations of financial instability. From the policy perspective, the growth and integration of world financial markets and the systemic repercussions that idiosyncratic failures might engender, have increased the importance of policy actions to safeguard financial stability. The present review joins the on-going debate on reinforcing financial stability on a global scale drawing from accumulated evidence on disruptions to financial stability, the responses and the new imperatives for re-defining the boundaries between State and markets. It is organized as follows. The first part reviews the various reasons that have been advanced as to why institutions should be particularly prone to instability. The second part examines the issue of instability in financial markets. The third section examines instability in market infrastructure. The subsequent section considers the possible responses. The fourth section give some suggestions for preventing and managing future financial crises. The final section give conclusions.

\section{Section I}

\section{Sources of Instability}

As a starting point, a distinction needs to be made between monetary stability and financial stability. Monetary stability can broadly be defined as the stability of the general price level; financial stability, on the other hand, refers to the smooth functioning of institutions, markets and infrastructure. The principal focus of the present article is financial stability. One can distinguish between two main sorts of financial instabilities: instabilities in institutions and instabilities in

\footnotetext{
${ }^{a}$ Lecturer at the Department of Economics,Jamia Millia Islamia(Central University),New Delhi,India.Email:som@del3.vsnl.net.in
} 
markets. Institutional instability exists when 'failure of one or a few institutions spreads and causes more widespread economic damage'. Market instability, on the other hand, is defined 'in terms of the wider impact that volatility in asset prices and flows can have on the economy' (Crockett, 1997). These apart, another potential source of instability, which has gained prominence in recent times, has been instability associated with disruptions to market infrastructure.

For a considerable period of time, the two standard explanations propounded to explain episodes of financial distress were characterized as cyclical and monetarist. The cyclical school focused on the various forces making for cyclical excess. The occurrence of periodic episodes of financial turmoil was attributed to external shocks or various forms of aberrant behavior (Kindleberger, 1978). The process is usually initiated when some favorable event leads to a bidding up of asset prices. Such a phenomenon is more likely to occur if a substantial period has elapsed since the last crash and the underlying pecuniary motive gathers momentum. In such a situation, a rise in price leads to further buying in anticipation of a continuation in the current price trend (bandwagon effect). Eventually, when prices reach overvalued levels or some external event occurs that shatters the confidence in the system, prices collapse, inducing a downward spiral, so that financial intermediaries, whose portfolios are financed by borrowing, are badly affected.

The monetarist view, on the other hand, contends that financial instability is not likely to become serious in the absence of an associated accommodation in the money supply. In this view, it is monetary policy mistakes that either initiate financial instability or engenders disruptions. Schwartz (1986), in particular, has labeled as 'pseudo-financial' crises those disturbances that are not accompanied by significant changes in the quantity of money.

Neither of these explanations is however, wholly satisfactory. The Minsky-Kindleberger hypothesis of cyclical excesses leaves an uncomfortable burden to be borne by irrational behavior, unsupported by any underlying rigorous microeconomic foundation. The monetarist view, although more self-contained theoretically, is rather limited in its approach since it does not explicitly internalize the possibility of disturbances arising from non-monetary factors.

Recent insights from game theory and the economics of decision-making under uncertainty have offered more satisfactory explanations as to why agents act in ways that produce instability in financial institutions. These insights have also provided strong microeconomic underpinnings to the earlier works.

\section{A. Fragility in Financial Institutions}

Recent advances in the theory of asymmetric information have provided significant insights into the vulnerability of financial intermediaries to a sudden loss of confidence. Asymmetric information gives rise to the problems of adverse selection, moral hazard and ex-post verification (Van Damme, 1993). In the market for loans, the asymmetric information process ensures that borrowers are relatively well-informed about the risk-return characteristics of the projects vis-àvis the lenders. Adverse selection therefore serves to ensure that a disproportionate number of 'bad' (risky) projects are presented for financing, leading to the phenomenon of credit rationing by lenders. When such problems become acute, there might not be any price at which buyers and 
sellers are willing to trade, given the uncertainty about the quality of the goods being traded. Such a situation necessitates an institutional mechanism to overcome this informational asymmetry. In the financial sector, such a mechanism is a financial intermediary. Such intermediaries can exploit economies of scale and scope in monitoring borrowers on behalf of investors and thereby reduce the cost of finance. In this context, the insight provided by Diamond (1984) was that such intermediaries (banks) could overcome the infinite regress problem by holding a portfolio of loans. Portfolio diversification eliminates the risk of investing in a single project and enables banks to offer depositors standard debt contracts, which offer a fixed return. Judged thus, depositors can arbiter banks merely in terms of whether they offer the going rate of return.

The vulnerability of banks results from the interaction of liabilities that are relatively more liquid than assets. Asymmetrically informed depositors may become nervous about the solvency of their banks and about the possibility that those other depositors may withdraw their deposits from the bank, thereby impairing the liquidity of the first group of depositors. Such fears and anticipations can lead to depositor runs, which could cause premature closure of even solvent banks and could be contagious among banks. In essence, depositors face a 'Prisoners Dilemma' problem, with each deposit withdrawal imposing negative externalities on other depositors. Mention may be made in this context of the fact that, prior to the 1930s, the US banking system suffered periodic banking panics and crisis, involving depositor runs, culminating in the banks runs of the early 1930s that led to the closure of over 9,000 banks between 1930 and 1933 (White, 1999).

If the dynamics of financial runs have become better understood as a result of advances in economic theory, it needs to be examined as to what are the factors responsible for initiating episodes of financial instability. Recent contributions to the literature have revealed the systematic influence of other phenomena, related to debt deflation, disaster myopia, herd behavior, adverse incentive structure, principal-agent problem and negative externalities. Fears of loss of liquidity sustain and intensify runs, but what causes the erosion of confidence in the first place? Typically, banks get into trouble because of deteriorating asset quality. They lend to activities that generate significant profits during boom times, but turn out to be vulnerable when underlying economic conditions become unfavorable.

The debt deflation theory (Fisher, 1933) contends that a shock to a highly indebted economy, implying significant default on interest and repayment obligations, can generate distress sale of assets, declining asset prices, consequent falls in general wages and prices, rising real debt burdens, calling-back of loans, contagious bank failures and a collapse of overall economic activity. In effect, excessive debt and deflation reinforce each other and drive the economy into a downward spiral.

Disaster myopia (Guttentag and Herring, 1984) occurs when lenders' assessment of the potential distribution of economic outcomes (subjective probabilities) differs from reality (objective probabilities). Disaster myopia can occur for a variety of reasons. For example, disastrous outcomes might occur so frequently that it is might prove impossible to assign with a reasonable degree of certainty any meaningful probability to the future occurrence of the event. Alternately, changes in policy regimes could push economic conditions well beyond the boundaries that were factored into account when the decisions were first made. In such circumstances, financial 
intermediaries may not find it worthwhile to devote scarce management time to analyzing such eventualities. In their view, such disasters are expected to engender countervailing action by the authorities designed to stave of its consequences.

A third aspect of lending action that gives rise to difficulties is what is referred to as herd behavior in financial markets-that is market instability occurs due to the possible role of asymmetric information among creditors(Banerjee, 1992). Herd behavior can be a manifestation of irrationality, but it can also reflect rational maximization under uncertainty.One basic implication of the assumption of asymmetric information is that each individual creditor may rationally respond more to the actions of other creditors taken as signals than to private information.It may be rational but socially inefficient for each decision maker to discard private information and base actions purely on the actions of earlier movers in a queue.The result is socially inefficient in the sense that it would be Pareto improving for each investor to ignore the actions of the others when making an individual decision. The fact that others are lending may be considered as invaluable information concerning the creditworthiness of a potential borrower. And importantly, managerial performance is generally judged relative to some market benchmark. The disincentives for being wrong in company are generally much less than for being wrong in isolation.

A fourth type of problem arises from the fact that management compensation structures can generate perverse incentives, which in turn, is an aspect of the principal-agent problem. Such problems arise because those involved in financial decision-making are compensated in ways not fully congruent with the success of their investment decisions. So, if an economic agent receives a handsome bonus if an investment is successful, but suffers no more than temporary loss of employment, if his decision adversely affects the employer, it might be rational for such an agent to favor high risk-return strategies vis-à-vis strategies with reasonable risk-return profiles.

The final aspect of asset quality problems arises from negative externalities. Negative externalities arise when some of the costs of an agent's decisions accrue to outsiders. Such externalities are often a pertinent feature, particularly of the banking industry, because of the relatively small cushion of own funds relative to total balance sheet size. The smaller the net worth of the bank, the less is the probability that its owners have to lose from adverse outcomes and the more inclined they are to pursue high-risk strategies or 'gamble for resurrection' (Dewartipont and Tirole, 1994).

Another reason why the financial industry is often thought to be particularly prone to systemic instability is because of the possible vulnerability to failure contagion across institutions. Contagion effects are often a significant feature of the financial sector for two main reasons. Firstly, there is a network of interlocking claims and liabilities through the inter-bank market and the payments and settlements system. These have become more pronounced and increasingly dominant in recent years, with the growing integration of national and international capital markets. Secondly, informational asymmetries make it more difficult for creditors to correctly judge the strength of financial institutions on the basis of publicly available information. As a result, creditors may be inclined to presume difficulties at one institution as indicative of potential vulnerability at other institutions with similar business structures. More importantly however, bank failure contagion is liable to (i) occur faster; (ii) spread more broadly, (iii) result in a larger number of failures, and (iv) result in significant losses to creditors. 
Last, but not the least, the costs that fall on the public budget provides the most persuasive evidence of the need to take public policy action to strengthen financial systems. The most prominent example of this pertains to the US S\&L debacle of the 1980s, the resolution costs of which are estimated anywhere between 2 and 4 percent of GDP. These numbers, however, pale in comparison to the costs incurred in a number of other countries. In France, the losses incurred by a single bank, Credit Lyonnais, are placed at around US\$ 30 billion, or over 2 percent of GNP. Honohan (1997) estimates the fiscal costs of resolving crisis in developing countries alone as being as much as US\$ 250 billion. Recent studies have placed the resolution costs of such crises anywhere between 5 to 55 per cent of GDP (Table 1). The resolution costs of these crises often falls on the banking system, and if the system is state-owned, on the Government. In such situations, the use of public money to support distressed institutions often endanger efforts to rein in budget deficits (Sundararajan and Balino, 1991). And even if budget deficits are viewed as (domestic) transfers rather than as real economic costs, they can compel the authorities towards less benign ways of deficit financing (e.g., an inflation tax); the rescue process itself can weaken the incentives for creditors to monitor the behavior of banks in the future.

Table 1 : Costs of Resolving Banking Sector Crises in Selected Economies

\begin{tabular}{ll}
\hline $\begin{array}{l}\text { Country (Period of crisis) } \\
\text { (per cent of GDP) }\end{array}$ & Estimate of cost/losses \\
\hline Latin America Economies & \\
Argentina (1980-82) & $13-55$ \\
Mexico (1994-95) & $12-15$ \\
& \\
African Economies & 25 \\
Cote d' Ivorie (1988-91) & 17 \\
Senegal (1988-91) & \\
& \\
Asian Economies & 9 \\
Sri Lanka (1989-93) & 5 \\
Malaysia (1985-88) & \\
Transition Economies & 14 \\
Bulgaria (1990s) & 10 \\
Hungary (1995) & \\
Industrial Economies & 17 \\
Spain (1977-85) & 10 \\
Japan (1990s) & $5-7$ \\
United States (1984-91) & \\
Source: Goldstein (1996) & \\
\hline
\end{tabular}

Source: Goldstein (1996) and World Economic Outlook (1998).

Note:The costs of recent banking and currency crises in the East Asia have been large.Between 1996 and 1998 the reversal of private capital flows to the five East Asian countries primarily affected(Indonesia,Korea,Malaysia,the Philippines and Thailand) was almost $\$ 150$ bn,equivalent 
to about $15 \%$ of the pre-crisis level of GDP(King,2001).

\section{B. Fragility in Markets}

The two markets in which instability has been most disconcerting and therefore subject to serious economic analysis have been the foreign exchange and the equity markets. These apart, instability in other markets, such as in the real estate market has been an important factor for the transmission of distress in the financial system, as evidenced from the recent experiences in South-East Asia (BIS Annual Report, 1997 and 1998).

Foreign exchange market instability can be divided into two main types. The first type, usually described as a currency crisis, takes place in a managed exchange regime when market participants lose confidence in the sustainability of the currency's current exchange rate and seek to reduce their exposure denominated in that currency. The common explanation offered for such a crisis is that the authorities of the country concerned have sought to peg their exchange rate at a level that is incompatible with the underlying macro policies. While the exchange rate may be maintained for a certain period through the use of reserves or otherwise, eventually the weight of market opinion implores that a change in the exchange rate is unavoidable. This position has however, not gone unchallenged. Several authors (Eichengreen, Rose and Wyplosz, 1993) have suggested that the exchange rate market may be subject to multiple equilibria. In such a setup of pegged exchange rates, so long as the exchange rate peg is considered 'credible', the evolution of domestic factor costs is consistent with external equilibrium. However, once a change in the exchange rate occurs, a new set of expectations governing price formation evolves and the exchange rate ceases to be in equilibrium. The second type of exchange market instability occurs in a floating exchange rate situation, when the amplitude of fluctuations in the market exchange rate exceeds that which can be explained on the basis of underlying fundamentals. This is usually termed as volatility.

Instability in equity markets cannot be easily explained by rational speculative behavior. Three standard explanations have been advanced as to why stock markets should be particularly prone to instability: (i) speculative excesses, (ii) instability in macroeconomic policies, and (iii) internal market dynamics. Any episode of market instability might contain elements of all the three explanations in varying degrees.

Speculative excesses come closest to the Minsky-Kindleberger explanation. As memories of the most recent crash fade out of public memory and economic recovery causes equity prices to rise, naïve investors jump on the bandwagon, intensifying an upward movement. There might be particular sectors that are favored, because of their perceived growth potential. Whatever the contributory causes, a process develops that leads to a bidding-up of asset prices. Eventually, reality sets in and prices crash.

Another potential source of stock market volatility lies in macroeconomic instability. Since equity prices represent the present discounted value of a future stream of earnings, they change whenever an event occurs that changes either the expected future income stream or the rate at which it is discounted by the market. When a major change in economic prospects occur, the prospective future shifts in income streams have an effect on the current prices.

Stock market declines have the potential to affect real economic activity through several 
channels. Firstly, the fall in private sector wealth will have a direct effect on willingness to spend out of current income, akin to the ratchet effect. Estimates produced at the time of US stock market crash of 1987 suggested that the negative effects on industrial country output from wealth effects would be less than one-half of one percent of GDP (World Economic Outlook, 1988). A second channel through which stock market declines affect real economic activity is via their effect on financial interme-diaries. If declining equity prices reduce the net worth of financial institutions and their customers, they may exacerbate asymmetric information problems and lead to a reduction in the level of financial intermediation (Mishkin, 1994). This, in turn, would make it harder to mobilize funds for productive investment and lead to a cumulative contraction in the level of output.

Apart from the exchange market and the stock market, the markets for fixed income securities (bonds) and real estate are also important, although they have attracted less attention in the literature. The most prominent instance of bond market instability occurred in 1994, when longterm bond yields rose sharply in most major markets, raising fears that certain financial institutions might find themselves in difficulty (Crockett, 1997).

A second potential source of macroeconomic instability lies in instability in the prices of real assets. The effect is more pronounced when the asset concerned is a large component of the private sector's real wealth, when changes in its price affect the profitability of different production technologies and when such price movements create generalized inflationary or deflationary pressures. The crisis in South-East Asia has been a testimony to the consequences of speculative excesses and its impact on real estate markets.

A third significant source of instability lies in fluctuations in commodity prices. The most striking example of this is to be found in two rounds of oil price increases in the early and late ' 1970 s, and the subsequent decline in real energy prices in the 1980s and 1990s, barring episodes in 1990 and 1999-2000.

\section{Fragility in Market Infrastructure}

The growth in volume of both domestic and international transactions has meant the transfer of an enormous volume of funds across the globe through the payments and settlements system. Consequently, the payments network has become one of the most likely channels of transmission of a generalized shock throughout the financial system. Most developed countries have switched over to a Real Time Gross Settlement (RTGS) system in the face of such vulnerabilities and several others have initiated a process of movement towards RTGS.

At the same time, the phenomenal growth in off-balance sheet (OBS) activities of banks, through the use of derivative instruments, has meant that credit exposures in settlement systems have increased at a pace much faster than real economic activity. The fear of a major bank failure because of OTC derivative activities appears to stem from two sources. First, the sheer size of banks' OTC derivative activities suggests that they may be exposed to substantial market and credit risks. Such concerns have been heightened in recent times, consequent upon the nearbankruptcy of Metallgesellschaft and Barings. Secondly, many fear that regulation, as well as managerial sophistication has lagged developments in the derivatives area, and, as a consequence, banks may be taking risks much more above the limits of prudence. These 
exposures, which often amount to a multiple of a bank's capital, have become the single biggest threat to the maintenance of stability in the financial system (Corrigan, 1996).

\section{Section III}

\section{Achieving Financial Stability}

It is therefore important to devise policies that can safeguard stability in the financial system, by improving the stability of financial institutions, containing excessive volatility and mitigating disruptions in market infrastructure.

\section{A. Improving the Functioning of Financial Institutions}

It has long been recognized that the specific characteristics of the banking industry makes it imperative that there should exist a lender-of-the-last resort (LLR) to provide the assurance of stability under all circumstances. Since banks are in the business of enhancing the creditworthiness and the liquidity of private financial obligations, they are vulnerable if, for whatever reason, their depositors seek early repayment of their claims at the same time. This is the argument adduced for the LLR function of the central bank, as a sort of catastrophic insurance coverage that should be used only in situations of extreme distress.

Another type of safety net is implicit or explicit deposit insurance. If depositors' are insured by an entity of unquestioned creditworthiness, then the incentive for sudden withdrawals in the case of any eventuality would stand curtailed. In India, a system of deposit insurance was established in the early 1960s and the insurance cover presently stands at Rs.1 lakh per depositor. Although the coverage of deposit insurance varies across countries, one might surmise that even in countries that do not have such mechanisms, in case of an eventuality, the authorities would take the necessary steps to ensure that the losses suffered by depositors are minimized.

Several variants of this approach, among others, a co-insurance fund (such as putting a certain percentage of each depositors account at risk) and a system of risk-based deposit insurance have been advanced in the literature. Although such schemes have the advantage of increasing the monitoring incentive of depositors, they nonetheless suffer from implementation problems.

The general problem of safety net mechanisms is that they exacerbate the problem of moral hazard(the tendency of the borrower to aggravate risk due to the inability of the creditor to observe debtors action leading to credit rationing). Not only is it inherently difficult for the lender to control the behavior of an economic agent, incentives might be created that reduce the desire of lenders to even attempt such control. If banks believe that they will be rescued in cases of illiquidity, they will have fewer incentives to prudently manage their portfolios; consequently, their interest in the institution in which they place their funds will be that much lower.

Several ways of dealing with the problem have been discussed in the literature. These include, among others, prudential regulation, narrow banking, increased disclosure and transparency and reducing settlement risk.

A time-tested approach to dealing with moral hazard is through regulation. The basic justification for bank regulation is that, in its absence, banks might, accidentally or otherwise, 
indulge in excessive risk-taking, so that even market discipline might prove insufficient to prevent this. Several complementary reasons have been cited as to why banks might be subject to regulation. These include (i) to protect the bank's customers from loss (consumer protection argument), (ii) to reduce the incidence of contagion (the systemic risk argument), (iii) to avoid losses to the deposit insurance fund or the LLR (the fiscal argument), and finally, (iv) to improve the allocation of resources in the financial system (the efficiency argument).

Two different approaches to bank regulation can be distinguished. The first focuses on controlling the activities that the regulated institutions can engage in, the second one focus on ensuring that they are adequately capitalized against the risks they run (Goodhart, 1995).

Risk-based capital requirements have not been without their critics. Objections have been raised, not so much to the principle of relating capital-holding to risk, but to the way risks are measured and the somewhat arbitrary process for setting minimum capital levels. Secondly, the focus in the original Capital Accord on credit risk, to the exclusion of other kinds of risks, was a subject of criticism. Thirdly, the rule of 'one-size-fits-all' aspect of the capital adequacy ratio was also the subject of intense debate and recent crises have only drilled home the point that baseline capital adequacy norms are not enough of a hedge against failures. In response to such criticism, the Basle Committee on Banking Supervision has proposed a Consultative Paper on the new capital adequacy framework, based on the three pillars of minimum capital requirements, supervisory review process and effective use of market discipline (BIS, 1999).

Given the growing disenchantment with capital adequacy standards, newer approaches to risk measurement are being discussed. These methods include, among others, Value-at-Risk models and pre-commitment approach. Under the Pre-commitment Approach, a bank itself decides how much capital it will hold within a given period to cover risks arising from its trading block. Sanctions will apply if the accumulated losses exceed the amount. The Value-at-Risk approach has emerged as a major tool for measuring market risk and is being used internally by banks for risk management and as a regulatory tool for ensuring the soundness of the financial system. However, the basic problem with such models lie in (i) obtaining adequate/high-frequency data and, (ii) devising a satisfactory way of handling the variability of credit exposures.

Another approach to maintenance of stability that has found support has been narrow banking. It has found considerable support in the writings of several writers (Litan, 1987). Institutions ('narrow' banks) would be authorized to accept deposits that can be withdrawn on demand. These banks would be required to restrict their investments to certain categories of safe assets. However, for several reasons, the proposal has not found much favour in policy circles. First, narrow banking might expose banks to increased market risks, as their entire asset portfolio comprises of marketable securities. Secondly, the implicit assumption behind narrow banking is that Government Securities have zero default risk attached to them. Such a proposition might not necessarily hold good, with instances of reputation of debt not having been uncommon in the history of financial markets. Thirdly, the proposal to convert a commercial bank into a narrow bank can be detrimental to the reputation of the bank management and the faith of its depositors.

An approach to improving the functioning of financial entities which has gained currency has been reliance on enhanced transparency and higher disclosure standards. Greater transparency, coupled with strict disclosure standards, would enable depositors to discriminate between risky 
and less risky banks, and strengthen managerial incentives by making banks management more accountable when losses occur. It has also been suggested that increased market discipline through improved transparency is likely to lead to a stable banking system. In the absence of disclosures, depositors and other creditors assume that banks will choose riskier positions and that the debt (deposits) will be priced accordingly. The solution then is for a bank to take riskier options. In contrast, with full disclosure, i.e., with its risk known, the bank can take less risky options. As a result, by enhancing market discipline, more effective disclosures is likely to engender a more stable banking system (Cordella and Yeyeti, 1997).

In India, the transparency aspect has been emphasized by expanding the coverage, timeliness and analytical content of the information provided in various publications by the supervisory authorities. The authorities have also mandated disclosure of some of the essential strength indicators and performance-related parameters as part of the 'Notes on Accounts' in the annually published accounts of banks.

Goldstein (1997) has documented the best and worst performing indicators of banking and currency crises in developed, developing and emerging market economies (Table 2). The better leading indicators seem to anticipate correctly somewhere between 80 and 100 per cent of the banking and currency crises over the period 1970-1995. The leading indicators that show the best forecasting accuracy also tend on average to send the earliest and most persistent signals of banking and currency crises.

Table 2: Currency and Banking Crises : Best vs Worst Performing Indicators

\begin{tabular}{lll}
\multicolumn{1}{l}{ Currency Crises Indicators } & Banking Crises Indicators \\
\hline BEST & Real Exchange Rate & Real Exchange Rate \\
Banking Crisis & Equity Prices \\
Exports & M2 Multiplier \\
Equity Prices & Real Output \\
M2/International Reserves & Real rate of interest on deposits \\
Real Output & Exports \\
\hline WORST-of-trade & International Reserves \\
Domestic/foreign real interest & Terms-of-trade \\
rate differential & \\
Imports & Excess real M1 balances \\
Lending interest rate/ & Lending interest rate/ \\
Deposit interest rate & Deposit interest rate
\end{tabular}


Source: Goldstein (1997).

Note:Radelet and Sachs(1998) find that the defining element of the East Asian crises has been vulnerability to panic by the creditors and subsequent withdrawal of funds by them,as measured by high ratios of short-term debt to reserves of foreign currencies in these countries.

Banking crises are however, found to be harder to forecast than currency crises. Recent work in this area, including Frankel and Rose (1996) and Honohan (1997) have emphasized the importance of monitoring foreign borrowings, particularly short-term liabilities denominated in foreign currency, to measure the degree of exposure to currency and inflation risks. The recent literature also focuses on the level of non-performing loans (NPLs). Empirical evidence suggests that the CAMELS-type assessment is statistically significant only if NPLs and capital adequacy are simultaneously considered (Gonzalez-Hermosillo et al., 1997) ${ }^{1}$. Other indicators to capture financial vulnerability include a measure of segmentation (proxied by inter-bank interest rate differential), the deposits to M2 ratio and aggregate stock indices. In surveying literature on these indicators, Gonzalez-Hermosillo (1999), using both micro and macro factors in explaining banking fragility concludes that the introduction of macro variables significantly improves the explanatory power of models based on micro-prudential indicators only.

In a recent study on financial sector surveillance, the IMF has identified a set of macroprudential indicators (IMF, 2000). These are categorised under two broad categories (a) aggregated micro-prudential indicators and (b) indicators of macroeconomic developments. However, the number of indicators included under these two heads is extremely large, numbering more than fifty, and it compromises on the principle of parsimony. It is therefore suggested that there is the need to develop a smaller and manageable set of indicators, primarily for purposes of periodic monitoring and data dissemination ${ }^{2,3}$.

\section{B. Improving the Functioning of Financial Markets}

Excessive volatility in asset prices can have adverse macroeconomic consequences. Therefore, policy makers need to ensure that undesirable price volatility is not generated either by their own macroeconomic policies or by the microstructure of financial markets.

It is possible to distinguish two sorts of price instabilities. One is the result of unnecessary variability in the underlying determinants of asset prices. Such variability might be the outcome of certain policy inconsistencies elsewhere in the system. Price instability in such cases often acts a signaling device, necessitating the need for remedial policy actions to bring them in line with other sets of domestic policies. A second sort of instability arises from imperfections in the price discovery mechanism (such as asset bubbles or over-shooting).

Although markets have become more powerful in ensuring that financial prices ultimately reflect fundamental economic determinants, they do not always do so in a smooth way. Lags in perceptions may mean that disequilibrium can exist for a while, perhaps because market opinion is divided about whether or not the situation is indeed sustainable, before corrective forces assert themselves. The risk lies in that the needed price adjustment will be more sudden and disruptive than it would have been had corrective action been taken earlier. 
Greater integration of global capital markets has had the consequence of giving rise to currency crises. There are three broad approaches that have been discussed in the literature that can be pursued when crises occur. Firstly, to organize a financial rescue; secondly, to allow events to chart their own course, accepting the possibility of an excessive depreciation and/or default on external debt and thirdly, to arrange a rescheduling and renegotiations of existing claims. Each of these approaches have their respective merits and drawbacks.

A financial rescue can limit the adverse effects on real living standards and help to limit the contagion effects elsewhere. If the financial support is based on appropriate conditions, it can also contribute to the adoption of corrective macroeconomic policies. On the flip side, the expectation that the international community will provide emergency assistance in the event of extreme debt-servicing difficulties risks worsening moral hazard. The second possibility of allowing market forces to trace their own route avoids the problem of moral hazard and in the end probably makes economic agents-borrowing Governments and external lenders-more cautious. The downside is that a laissez faire approach would involve larger costs in those crises that did nevertheless occur. The deadweight loss in terms of output is likely to be higher than in circumstances where international assistance was available in support of a well-designed adjustment program.

The demerits of both the financial rescue as well as the laissez faire approach have led to a search for alternative ways of dealing with sovereign liquidity crises. An approach that has been advocated in the literature has been the re-schedulement/renegotiation of loans. Such an approach has obvious attractions, but has its pitfalls too. For one, legal frameworks differ so much across countries that it would be well nigh impossible to agree on a common approach at the sovereign level. For another, the ultimate sanction as in domestic bankruptcy proceedings, the take-over and liquidation of the debtor entity is not available at the sovereign level.

Supervisors of financial institutions seek to ensure that firms hold sufficient capital and liquidity to meet unforeseen market conditions. An important way to ensure stability of markets is by addressing some of the underlying factors that make for excessive price volatility. Non-financial firms in countries with high and variable inflation tend to be vulnerable to economic shocks, because their debt tends to be of short duration and denominated in foreign currency. Highly variable inflation reduces the credibility of policy makers, making it difficult to promote recovery from crisis. At the macro-economic level, this means avoiding abrupt changes in policy that cause economic agents to re-assess the value of debt and equity instruments. Such abrupt changes might be deemed as necessary when a unsustainable situation has been allowed to persist for long and an initial corrective move on the part of the authorities is perceived as heralding a turning point.

\section{Improving the Financial Market Infrastructure}

The growth of financial transactions generally means that financial intermediaries find themselves with increasingly large, though very short-term credit exposures in the payments system. At the same time, given the complexity and unpredictability of inter-bank payments flows, it becomes extremely difficult for financial institutions to form a view of the indirect exposures that they face through the settlement position of their counter-parties vis-à-vis others. 
An aspect of market infrastructure which has received scant attention in the literature is the legal framework. In developing and transition economies, there is often a basic need for workable laws on contract, collateral and bankruptcy proceedings, as well as the need to streamline court proceedings for rapid and effective remedy. But the issue also extends to developed legal and judicial systems, because the continual state of innovation and evolution of new financial products can outrun existing legislation and raise finer points of law.

An important aspect of market infrastructure which is gained prominence in policy discussions is the issue of corporate governance. Corporate governance in its wide connotation covers a variety of aspects, such as protection of shareholders' rights, enhancing shareholders value, Board issues including its composition and role, disclosure requirements, integrity of accounting practices and internal control systems (Reddy, 1999).

\section{Section IV}

\section{Preventing and Managing Future Crises}

It is useful to distinguish between measures to improve economic performance and prevent financial crises from occurring in future and ways to resolve crises once they have occurred.The former is dealt in the sub-section IV.1 while the latter in the sub-section IV.2.

\section{IV.1:Preventing Financial Crises:}

Crises prevention should be the core of the policies for both developed and developing economies and also the international financial institutions.In terms of prevention, recent experience suggests the following lessons for future.

1)There must be enhanced efforts by countries to identify incipient vulnerabilities in national and international financial systems.In this respect,the IMF can play a helpful supportive role by providing assessments of vulnerabilities as part of the Article IV process, the new joint IMF/World Bank financial sector assessment programs and debt management guidelines and technical assistance on the data requirements implied by the need to monitor national balance sheets.Moreover,there should be concerted procedures to understand better the sources of systemic risk and to formulate effective financial,regulatory and supervisory policies to mitigate such situations.It is important that borrowing countries,especially those without a track record of international borrowing, monitor and manage the maturity and currency composition of their national balance sheet.Most countries have inadequate information on the composition of their external liabilities, especially those of private sector.Neverthless,monitoring and managing the exposures of the public and financial sectors are important to avoid build up of potential vulnerabilities.

2)Countries should think more about the provision of self insurance against a liquidity crisis in the face of the large bail out packages required to curb systemic crises.Building up of foreign exchange reserves is a strategy which can be carried out by countries.A potentially superior alternative is the creation of contingent credit facilities with both official and private sector creditors.

3)Experience has shown the value of borrowing establishing good relationships with creditors 
well before any possibility of difficulty in repayment arises. The creation of investor relations program and the regular briefing of creditors about developments in economic policy can play a role in providing the information which the market requires to assess the riskiness of sovereign loans.There must be improved arrangements to ensure that consistent international rules and arrangements apply across all significant financial institutions and there are procedures to ensure continous flow of information among the authorities responsible for financial stability.The second aspect of relationships with creditors is the assertion of collective action clauses in sovereign debt contracts.

4)In the long run the best way to avoid the problem of liquidity crises is for the composition of capital flows to emerging markets move away from debt,both bank and bond,finance towards portfolio equity and preferably direct investment.However,there are still biases towards debt rather equity finance in capital flows to emerging markets. One of these is deposit insurance(as discussed above) in both creditor and debtor countries which makes it more difficult for the authorities to avoid being seen as providing some implicit support to international loans by domestic banks. There is no easy answer to this problem but a shared concern in both borrowing and lending countries is the implicit insurance which both sides are giving to large parts of the financial system.The moral hazard so created is not restricted to international lending but it does affect the incentives for the form of investment in emerging markets. There is also a need to guard against institutional or regulatory mechanisms-both international and domestic-which favours short-term over longer maturity capital flows.In the long run the solution is for emerging markets to create legal structures and a stable economic policy environment that provide the confidence to support inward equity investment in their economies.

5) Greater transparency on appropriate codes and standards allows better informed decisions by both borrowers and lenders and reduces the risk of contagion by allowing markets to differentiate among borrowers.If it is accepted that codes and standards are likely to reflect different stages of development then it is important that countries make clear to which codes and standards they are actually adhering.Countries should not be able to opt out of 'transparency about transparency'(King,2001).Following the production of pilot transparency on a number of countries,including the UK and Argentina,the IMF has now made rapid progress in producing reports on observance of standards and codes(ROSCs).As of April 2001,110 ROSC modules had been completed for 43 countries of which 76 have been published covering 31 countries.India has recently had a ROSC published on fiscal transparency.

In the field of transparency ,the key element of the new partnership are,first, a commitment by emerging market economies to implement transparency about transparency by publishing ROSCs, and, on the part of the international community, new opportunities for emerging markets to engage in the process of constructing and developing codes and standrads. There should be more effective procedures to ensure that international rules and standards of best practices are developed and implemented and that gaps in such standards are effectively identified and filled.There is encouraging evidence of greater collaboration and consultation between developed and developing countries in the design and implementation of the core standards-for example,on banking,securities and insurance regulation,data,payments system,insolvency and transparency of moneatry,fiscal and financial policies.However,it is important that new ways of involving emerging market countries in the process of designing and implementing standards and codes are found. 
6) It is being empirically tested that stricter restrictions on allowable bank activities will not necessarily limit risk taking behavior(Barth,Caprio,Jr. and Levive,1999). The note that countries where bank activities are restricted the likelihood of a banking crises may be greater. There may be two possible forces that may work to produce such results.First,to the extent that narrower banking activities(e.g.,making loans) and broader financial activities(e.g., engaging in securities and insurance activities) are not highly and positively correlated,banks in countries allowing broader powers are able to benefit by being more diversified in their operations. This reduces the likelihood of both failures and crises(c.f Caprio and Wilson,1997 for evidence identifying a link between a lack of diversification and bank failures in selected countries).Second, harsher restrictions on banking activities like imposing deposit interest rate ceiling may lower franchise value either by limiting profits(reducing economies of scale and scope) or by increasing the variability of profits(leaving average profits unchanged but reducing the market value of those profits to the extent that investors prefer less to more volatility).Bankers frequently lament that restrictions on their ability to engage in investment banking activities excludes them from more profitable lines of business.However,it should not be the case, at least in the long run,that one sector has a consistently higher profit rate than another,other thing being equal.For this reason,the economies of scale and scope argument is more persuasive with respect to eliminating the restrictions.

\section{IV.2:Resolving Crises Situation:}

The main area in which further progress is required is the resolution of financial crises. The problem would be easier solved were it possible to distinguish between two rather different sources of crises-a liquidity- based problem caused by a currency or maturity mismatch in a country's national balance sheet despite a sustainable macroeconomic and debt position;and a fundamental-based problem which means that the debt burden is unsustainable or the exchange rate or other key macroeconomic and microeconomic policies need to be altered.In the former case the provision of liquidity support by the international community might help to bridge to a position in which country could re-engage with its private creditors.In the latter case the main requirement is not liquidity support but a change in macroeconomic,microeconomic and debt management policies.

Liquidity runs typically occur because of a co-ordination failure among creditors. There are two solutions to this co-ordination problem. The first is the lender of last resort that is able to provide liquidity support quickly and on a large scale for a short period to enable the affected country to meet its obligations.Such loans would normally be short lived and should be seen as last not first resort.The second solution to the co-ordination problem is for the borrower to impose a temporary suspension of payments to create a "time out" during which the borrower can negotiate directly with the creditors and so arrange a new profile of repayment of debt(King,2001).Both approaches, if implemented consistently over time can provide an efficient solution to the co-ordination problem and eliminate the incentives for a liquidity run.

However,as pointed out earlier the lender of resort approach carries with it the risk of introducing significant moral hazard into the loan market.If lenders believe that sovereign borrowers are likely to be bailed out then their incentive to assess the riskiness of their loans will 
diminish.Equally,borrowing countries will find it more attractive to claim that the measures necessary to continue servicing their debt are 'politically impossible' if they believe that there is an international deep pocket willing to extend loans and defer the moment when the national balance constraint is binding.

The way out be that the IMF lending need to be compromised but within strong presumptive limits(King,2001).These presumptions then would provide the backstop for debtor-creditor negotiations and help condition expectations in financial markets.A key principle underlying this approach is that the international community needs to set out as clearly as possible the criteria that will govern the size and scope of IMF lending.Since most agree that there are limits on IMF lending(because of the moral hazard problem and the need of large bailout packages in short time),there is a merit in explaining those limits to both potential borrowing countries and their private creditors. This would enable debtor countries to better plan their policies.Exceptional lending above this presumptive limit would be possible in order to provide operational flexibility in extreme cases -for example,those threatening systemic stability.

A key principle of any crises resolution framework is that decisions on a sovereign's debt are the responsibility of the borrowing country in consultation with its private sector creditors. There are range of options open to debtors in dealing with their creditors at time of crises.Countries with a good track record of repayment and long standing relationships with their creditors may be able to borrow more from the international market.Others,facing more severe liquidity pressures may seek to undertake voluntary rescheduling or rollover of debt by bringing together all or some of their major creditors as in the recent cases of Korea and Brazil.Those facing unsustainable debt positions may seek to negotiate market based write downs of their debt as in the cases of Ukraine,Pakistan and Ecuador.And in yet another set of cases a country may find it necessary to impose a temporary timeout on payments to all creditors to give themselves some breathing space to address macroeconomic,microeconomic or co-ordination problems. The exercising any of these options must rest with the debtor country.

In summary both borrowing countries and private sector creditors must expect that except in exceptional cases of systemic concern the limits on IMF lending or Central Government support means that they alone will be responsible for dealing with a resolution of problems concerning debt repayment.Standstills and debt restructuring will be only one of many options open to negotiation between debtors and creditors. The IMF should not attempt to impose a solution on borrowing countries.It should be willing to lend in arrears in circumstances where countries have chosen the route of a standstill and its associated conditions.But it should not create expectations that exceptional access is the norm.

\section{Section V}

\section{Conclusions}

The paper reviews the sources of market failure in financial institutions and markets and what can be done to alleviate them. It examines game-theoretic explanations for financial instability, in particular the role of asymmetric information in generating destabilizing behavior. In the area 
of remedies, the paper analyses the potential contribution of official safety nets and what can be done to minimize the associated moral hazard. In this context, it discusses the role of regulation and transparency.Countries having more restrictive financial regulatory and supervisory standards does not necessarily achieve financial stability. However,development and implementation of international supervisory and regulatory rules and standards of best practices,the design of IMF lending and wider agenda of trade liberalization and international cooperation can help in preventing or managing future crisis.Progress can be made by closer cooperation between the developed and developing countries.

There is overwhelming evidence that financial stability provides a conducive environment for efficient resource allocation and rapid economic growth. The integration of international capital markets and the globalization of major financial institutions has made the objective of maintaining financial stability increasingly important, but overtly complex.

In an increasingly deregulated world, wherein most emerging market economies have been encompassing deregulation in varying degrees, one aspect of stability which has largely bypassed the attention of observers has been the issue of timing and sequencing of reforms. The sequencing of reforms that takes into account the institutional imperatives has a better chance to succeed and avoid disruptions to the financial system. Experience is indicative of the fact that even with all the sequencing and timing problems resolved, financial sector reforms needs to be preceded by the real sector reforms, good corporate governance, a firm control of the fiscal deficit as well as consistent macro-economic and microeconomic policies.

Recent theoretical work has greatly increased understanding of the forces making for instability in the financial system. One no longer needs to rely on psychological explanations as to why bank runs occur or why financial prices move by more than what is justified on the basis of underlying economic fundamentals. The understanding of the microeconomics of financial market behavior is an important part of the policymakers' tool-kit in the search for a system that is stable enough to facilitate inter-temporal resource allocation decisions, yet flexible enough to allow prices and institutional structures to adapt through time, and to provide a proper range of incentives for good decisions and penalties for bad decisions.

\section{Notes}

1. Non-performing loans may be of particular relevance, as they give an indication of risks to capital adequacy from future write-offs (Davis et al., 1999).

2. Davis et al. (1999) has outlined the types of financial data required for macro-prudential surveillance. As Davis et al. observes, the essential point is to seek to detect emerging patterns of financial stability in advance and gauge their gravity when they occur by observing the overall pattern of economic and financial developments in a judgemental manner, informed by the events of the past that have entailed systemic risks, and with a broad conceptual framework derived from theory to identify appropriate danger signals (italics in original).

3. Patra and Roy (1999) have attempted to delineate the optimum thresholds of financial stability in India for the period 1970/71-1997/98. The variables used in their setup include (a) Real GDP growth, (b) inflation rate, (c) international reserves, (d) money multiplier and (e) export growth (in dollars).

\section{References:}


Banerjee, A.V. (1992): “A Simple Model of Herd Behaviour”, Quarterly Journal of Economics, 107, pp.797-817.

Bank for International Settlements, Annual Report, various years.

Bank for International Settlements (1999): A New Capital Adequacy Framework, June, Basle: Switzerland.

Barth,J.R,Caprio,G.J. and R Levine(1999),"Financial Regulation and Performance:Cross Country Evidence.",Policy Research Working Paper No.2037,The World Bank,Development Research Group Finance,January.

Caprio,G and B.Wilson(1997),"On putting all the eggs in one basket:the role of diversification in banking'",paper presented at the World Bank-IMF Annual Meeting,September.

Cordella, T and E.L. Yeyeti (1997): “Public Disclosures and Bank Failures”, IMF Working Paper No. 96, IMF: Washington D.C.

Corrigan, G. E.(1996): “A Perspective on Recent Financial Disruptions”, Federal Reserve Bank of New York Quarterly Review, 14, pp.8-15.

Crockett, A (1997): “Why is Financial Stability a Goal of Public Policy?”, Symposium on Financial Stability in a Global Economy, Federal Reserve Bank of Kansas City, Kansas, USA.

Davis, P.E., R. Hamilton, R. Heath, F. Mackie and Aditya Narain (1999): Financial Market Data for International Financial Stability, Centre for Central Banking Studies, Bank of England: London.

Dewartipont, M. and J.Tirole (1994): The Prudential Regulation of Banks, Cambridge, MA, MIT Press.

Diamond, D. (1984): "Financial Intermediation and Delegated Monitoring”, Review of Economic Studies, 51, pp.393-414.

Eichengreen, B., A.Rose, and C.Wyplosz (1993): "Exchange Market Mayhem: The Antecedents and Aftermath of Speculative Attacks”, Economic Policy, 27, pp.251-311.

Fischer, I (1933): “The Debt-Deflation Theory of Great Depressions”, Econometrica, 1, pp.337-357.

Frankel, J. and A.K. Rose (1996): “Currency Crashes in Emerging Markets: An Empirical Treatment”, Journal of International Economics, 41, pp. 351-366.

Goldstein, M (1996): The Case for an International Banking Standard, Institute for International Finance, Washington, D.C.

Goldstein, M (1997): “Commentary : The Causes and Propagation of Financial Instability: Lessons for Policymakers”, Symposium on Financial Stability in a Global Economy, Federal Reserve Bank of Kansas City, Kansas, USA.

Gonzalez - Hermosillo, B., Pazarbasioglu and R. Billings (1997): "Determinants of Banking System Fragility: A Case Study of Mexico”, IMF Staff Papers, 44, pp. 295-314.

Gonzalez-Hermosillo, B (1999): "Determinants of Ex-ante Banking System Distress: A Micro Macro Empirical Exploration of Some Recent Episodes”, IMF Working Paper No.33, IMF: Washington D.C.

Goodhart (1995): “Why Do Banks Need a Central Bank? Should Regulation and Supervision be Separated?” Oxford Economic Papers, 22, pp.33-48.

Guttentag, J.M. and R.J.Herring (1984): “Credit Rationing and Financial Disorder”, Journal of Finance, 39, pp.1359-1382. 
Honohan, P (1997): “Banking System Failures in Developing and Transition Countries: Diagnosis and Predictions”, BIS WP No.39, Basle, Switzerland.

International Monetary Fund, World Economic Outlook, various years.

International Monetary Fund (2000): “Macroprudential Indicators of Financial System Soundness”, IMF Occasional Paper No. 192, IMF: Washington D.C.

Kindleberger, C.P (1978): Manias, Panics and Crashes: A History of Financial Crises, New York, Basic Books.

King,M(2001),"The International Financial System:A New Partnership",First K.B.Lall Lecture by the Deputy Governor,Bank of England, held at the Indian Council for Research on International Economic Relations,New Delhi.

Litan R.E. (1987): What Should Banks Do? The Brookings Institution, Washington, D.C.

Mishkin, F.S. (1994): “Preventing Financial Crises: An International Perspective”, NBER Working Paper No.4636, NBER, New York.

Patra, Michael, D and S.Roy (1999): "Financial Stability and the Role of the Central Bank: The Indian Experience”, Paper presented at the Workshop on Central Bank Responsibility for Financial Stability, Centre for Central Banking Studies, Bank of England.

Radelet,S. and J.Sachs(1998),"The East Asian Financial Crisis:Diagnosis,Remedies,Prospects",Brooking Papers on Economic Activity,1.

Reddy, Y.V. (1999): “Corporate Governance in Financial Sector”, RBI Bulletin, August, pp. 993-1004.

Schwartz, A.J. (1986): “Real and Pseudo Financial Crises”, in E.Altman and A.W.Sametz (eds.) Financial Crises, New York, Wiley.

Sundararajan, P and T.Balino (1991): Banking Crises: Cases and Evidence, International Monetary Fund, Washington, D.C.

Van Damme, E (1993): “Banking: A Survey of Recent Microeconomic Theory”, Oxford Review of Economic Policy, 10, pp. 14-33.

White, W.R. (1999): "Evolving International Financial Markets: Some Implications for Central Banks”, BIS Working Paper, No.66, BIS: Switzerland. 